\title{
Prediction of ecological niches and carbon export by appendicularians using a new multispecies ecophysiological model
}

\author{
F. Lombard ${ }^{1,2, *}$, L. Legendre ${ }^{1}$, M. Picheral ${ }^{1}$, A. Sciandra ${ }^{1}$, G. Gorsky ${ }^{1}$ \\ ${ }^{1}$ Laboratoire d'Océanographie de Villefranche, Université Pierre et Marie Curie Paris 06 and CNRS, UMR 7093, LOV, \\ 06230 Villefranche-sur-Mer, France \\ ${ }^{2}$ Present address: DTU Aqua, Technical University of Denmark, Kavalergården 6, 2920 Charlottenlund, Denmark
}

\begin{abstract}
We developed, calibrated and validated an ecophysiological model that represents food consumption, growth and production of faecal pellets and discarded houses during the life cycle of Oikopleura dioica, O. longicauda, O. fusiformis and O. rufescens, which are among the most abundant appendicularian species in the ocean. The forcing variables of the model are temperature $(T)$ and food concentration. We calculated the growth rates of the 4 species and predicted the dominant species as a function of environmental conditions on 3 ecological applications. Firstly, we used the seasonal changes in $T$ and chlorophyll $a(\mathrm{chl}$ a) in the English Channel to predict the seasonal succession of the 4 species. Secondly, using sea surface $T$ and chl a data from the MODIS satellite, we determined the dominant appendicularian species over the World Ocean, thus providing a first-ever description of appendicularian biogeography over the 4 different seasons. Thirdly, we applied our model to in situ observations performed with the Underwater Video Profiler during the POMME 3 cruise in the Northeastern Atlantic in 2001. In areas of high appendicularian concentrations (135 ind. $\mathrm{m}^{-3}$ ), the appendicularians grazed daily only $0.6 \%$ of the stock of total particulate carbon. Of this grazed material, $21 \%$ was used for growth, $14 \%$ was respired and $65 \%$ was lost as detritus. Based on our model predictions, we concluded that at 2 of the 4 sampling stations, the integrated mass of detritus produced by the appendicularian population equalled or exceeded the carbon flux recorded in sediment traps at $200 \mathrm{~m}$ depth. This indicated high rates of disaggregation and/or consumption of these particles during their transit to depth.
\end{abstract}

KEY WORDS: Zooplankton · Appendicularians · Modelling $\cdot$ Biogeography $\cdot$ Seasonal successions · Carbon flux

\section{INTRODUCTION}

Appendicularians are among the most common members of mesozooplankton communities, where they are often the second numerically most abundant group after copepods (Landry et al. 1994). They contribute to actively transfer biogenic carbon to depth (Robison et al. 2005) through their large production of fast-sinking discarded houses and faecal pellets (López-Urrutia \& Acuña 1999, Sato et al. 2003, Alldredge 2005), high growth rates (Hopcroft \& Roff
1995), short life cycles (Fenaux 1976), and ability to feed intensively on small particles (Fernández et al. 2004). They also play an important role in marine food webs as grazers of the ecosystem's microbial components and food source for lager organisms (Gorsky \& Fenaux 1998, Zubkov \& López-Urrutia 2003, Purcell et al. 2005). Because different appendicularian species have different metabolic rates, notably their filtration rate and production of discarded houses (Sato et al. 2003, 2005), they have different effects on the ecosystem (López-Urrutia et al. 2005) and, thus, on biogeo- 
chemical fluxes. Hence, it is important to identify these organisms to the species level in order to estimate their potential ecological or biogeochemical roles.

Appendicularians are not well sampled using traditional in situ collection methods such as plankton nets, pumps or bottles. Firstly, because the distribution of appendicularians is often patchy (Fenaux et al. 1998), discrete sampling may miss part of the population. Secondly, plankton nets often underestimate true appendicularian concentrations (Fenaux \& Palazzoli 1979, Fenaux 1986, López-Urrutia et al. 2005) when compared with water sampling methods (e.g. Niskin bottles) or video observations (Benfield et al. 1996, Remsen et al. 2004). This is mainly due to extrusion of organisms through the net mesh, sticking within the net, and destruction of fragile forms when captured (Gallienne \& Robins 2001, Halliday et al. 2001, Hopcroft et al. 2001, Warren et al. 2001). Thirdly, species identification of organisms from net samples is often impossible due to partial destruction of specimens.

Recent advances in zooplankton imaging technology have allowed direct in situ observations at small spatial scales. These instruments, such as the underwater video profiler (UVP; Gorsky et al. 1992, 2000a, Stemmann et al. 2008), the video plankton recorder (VPR; Davis et al. 1992) and the shadowed image particle profiling and evaluation recorder (SIPPER; Samson et al. 2001), provide high-definition images that allow for the recognition of different taxonomic groups with a high spatial resolution. These imaging devices are often more effective than nets for studying the distributions of fragile plankton (Norrbin et al. 1996, Dennett et al. 2002, Stemmann et al. 2008). Unfortunately, because images do not provide all the details needed for taxonomic identification, data from this type of observations are often limited to broad taxonomic categories (Stemmann et al. 2008), and identification of appendicularians from images of their houses is limited to a few species only (Flood 2005).

Because of these limitations, taxonomic studies on appendicularians are not often realized in traditional sampling or are impossible in the case of imaging device observations. There is then a need to give a first order estimation of the taxonomical nature of the assemblage. The species composition of appendicularian populations seems to be largely determined by temperature $(T)$, salinity and food concentration (Fenaux et al. 1998, López-Urrutia et al. 2005). Because there is generally a clear temporal succession of species (Fenaux et al. 1998), it may be possible to determine the potentially best-adapted species for given sets of environmental conditions.

In the present study, we propose a new modelling approach with multispecies calibration of a metabolic balance model (Lombard et al. 2009). This model is based on appendicularians' physiology, and the central objective of the present study is to assess the extent to which the physiology of different species can explain their spatio-temporal distributions at sea. We illustrated the use of the model with 3 ecological applications, which were based on the ecological niches of 4 appendicularian species. We determined the niches following the approach of Levins (1968), who used the environmental hypervolume in which one species has the greatest fitness compared to others. In the first application, we predicted the seasonal succession in the English Channel, and compared the prediction with existing data. In the second application, we provided a first estimation of the ocean-wide biogeography of dominant species and compared the results with literature data. In the third application, we estimated the effects of appendicularians on water-column biogeochemical carbon processes at stations in the Northeastern Atlantic Ocean.

\section{MATERIALS AND METHODS}

Model. The overall organisation and behaviour of our model was described by Lombard et al. (2009) for the appendicularian Oikopleura dioica (Appendix 1). This physiological model defines appendicularian growth as the difference between the intake of carbon (filtration, ingestion, assimilation) and the metabolic losses and expenses (faecal pellets, respiration, house secretion). The forcing variables are $T\left({ }^{\circ} \mathrm{C}\right)$ and food concentration $\left(\mu g \mathrm{C}^{-1}\right)$. The simulated variables (carbon units) are the appendicularian trunk and gonad mass, the mass of secreted houses, and the losses in discarded houses, faecal pellets and respiration. Here, we adapted the model for 3 additional appendicularian species, i.e. O. longicauda, O. fusiformis and O. rufescens (see below). The 4 modelled species are among the most abundant appendicularian species in the global ocean (Fenaux et al. 1998). The parameters used in the model are listed in Table 1.

The parameters controlling filtration and ingestion $\left(\begin{array}{llllll}f_{1} & t_{10 f,} & b & k_{f \prime} & i_{\max } & k_{i}\end{array}\right)$ of Oikopleura longicauda, $O$. fusiformis and $O$. rufescens were calculated directly from the data in Sato et al. (2005). For O. longicauda, the parameters controlling respiration $\left(r_{2}, t_{10}\right.$ and $\left.a\right)$ were estimated from experimental results (Gorsky et al. 1984b) and from Lombard et al. (2005). Parameters corresponding to respiration and first house production during the larval stage were calibrated according to the length of the embryonic phase and the relative mass of a single house (Sato et al. 2003). The other parameters were calibrated using least-square minimization (Nelder-Mead simplex method) between model outputs and experimental observations of growth that 
Table 1. Oikopleura spp. Model parameters: symbol, description, value and units for the 4 appendicularian species. wd: dimensionless

\begin{tabular}{|c|c|c|c|c|c|c|}
\hline \multirow[t]{2}{*}{ Symbol } & \multirow[t]{2}{*}{ Description } & \multirow[b]{2}{*}{ O. dioica } & \multicolumn{3}{|c|}{ _ Values } & \multirow{2}{*}{ Units } \\
\hline & & & $\begin{array}{l}\text { O. longi- } \\
\text { cauda }\end{array}$ & $\begin{array}{l}\text { O. fusif- } \\
\text { ormis }\end{array}$ & $\begin{array}{l}\text { O. rufes- } \\
\text { cens }\end{array}$ & \\
\hline$r_{1}$ & Respiration rate at $0^{\circ} \mathrm{C}$ during the development phase & 0.07276 & 0.01 & 0.035 & 0.035 & $\mu g C \mu g C^{-1} d^{-1}$ \\
\hline$r_{2}$ & Respiration rate at $0^{\circ} \mathrm{C}$ during the growth phase & 0.1086 & 0.048 & 0.1416 & 0.1163 & $\mu g C \mu \mathrm{gC}^{-1} \mathrm{~d}^{-1}$ \\
\hline$t_{10}$ & 10th root of the $Q_{10}$ coefficient for respiration & 1.08717 & 1.15 & 1.1 & 1.1 & wd \\
\hline a & $\begin{array}{l}\text { Exponent of the allometric equation for } \\
\text { respiration at } 0^{\circ} \mathrm{C}\end{array}$ & 0.75 & 0.9 & 0.9 & 0.9 & wd \\
\hline$h_{0}$ & $\begin{array}{l}\text { House secretion rate at } 0^{\circ} \mathrm{C} \text { during the } \\
\text { development phase }\end{array}$ & 0.022 & 0.004 & 0.03 & 0.03 & $\mu g C \mu g C^{-1} d^{-1}$ \\
\hline th & First house deployment threshold & 0.153 & 0.053 & 0.12 & 0.23 & wd \\
\hline$t_{10 f}$ & 10th root of the $Q_{10}$ coefficient for filtration & 1.07 & 1.103 & 1.091 & 1.0896 & wd \\
\hline$k_{f}$ & Half-saturation constant for the filtration & 150 & 518 & 301 & 259 & $\mu g C 1^{-1}$ \\
\hline$b$ & Exponent of the allometric equation for filtration at $0^{\circ} \mathrm{C}$ & 0.9 & 0.75 & 0.9 & 0.87 & wd \\
\hline$f$ & Maximum food intake for filtration at $0^{\circ} \mathrm{C}$ & 3.7 & 8.736 & 7.8 & 5.28 & $\mu g C \mu g C^{-1} d^{-1}$ \\
\hline$i_{\max }$ & Maximum fraction of food not ingested & 0.85 & 0.99 & 0.99 & 0.8 & wd \\
\hline$a_{\max }$ & Maximum fraction of food not assimilated & 0.9 & 0.99 & 0.9 & 0.8 & wd \\
\hline$k_{a}$ & Half-saturation constant for the assimilation efficiency & 130 & 120 & 300 & 80 & $\mu g \mathrm{Cl}^{-1}$ \\
\hline$k_{i}$ & Half-saturation constant for the ingestion efficiency & 200 & 150 & 120 & 80 & $\mu g C 1^{-1}$ \\
\hline$f_{h}$ & $\begin{array}{l}\text { Fraction of assimilated food allocated to } \\
\text { houses secretion }\end{array}$ & 0.35 & 0.57 & 0.57 & 0.41 & wd \\
\hline$p$ & $\begin{array}{l}\text { Fraction of assimilated food allocated to gonad } \\
\text { during growth phase }\end{array}$ & 0.13 & 0.092 & 0.0946 & 0.1298 & wd \\
\hline$b 1$ & $\begin{array}{l}\text { Exponent of the Holling type III relationship for the } \\
\text { gonad matter allocation increase after hatching }\end{array}$ & 2 & 2 & 2 & 2 & wd \\
\hline$k 1$ & $\begin{array}{l}\text { Half-saturation constant for the gonad matter } \\
\text { allocation increase after hatching }\end{array}$ & 0.06 & 0.069 & 0.066 & 0.069 & wd \\
\hline$b 2$ & $\begin{array}{l}\text { Exponent of the Holling type III relationship for the } \\
\text { gonad matter allocation increase during maturation }\end{array}$ & 6 & 6 & 6 & 6 & wd \\
\hline$k 2$ & $\begin{array}{l}\text { Half-saturation constant for the gonad matter } \\
\text { allocation increase during maturation }\end{array}$ & 0.32 & 0.48 & 0.447 & 0.48 & wd \\
\hline St & Spawning threshold & 0.76 & 0.7 & 0.7 & 0.7 & wd \\
\hline$S b_{0}$ & Mass of 1 egg (mass of structural biomass at $t=0$ ) & 0.038 & 0.04 & 0.04 & 0.06 & $\mu g C$ \\
\hline$G_{0}$ & Mass of gonad at $t=0$ & 0.00076 & 0.0012 & 0.0008 & 0.0012 & $\mu \mathrm{gC}$ \\
\hline
\end{tabular}

included generation time (Fenaux \& Gorsky 1983, Sato et al. 2003), and energy budget of house secretion (Sato et al. 2003). This algorithm made it possible to locate the set of parameters that minimized the differences between the model and the experimental data.

A specific carbon to chlorophyll a ratio (C:chl a) (Flynn et al. 1994) obtained with the haptophyte Isochrysis galbana was used for the experimental results (i.e. the experiments that involved the appendicularian species; Sato et al. 2003). All experimental data and in situ observations expressed in chl a concentrations were transformed into carbon units using the variable C:chl a conversion factor issue from the PISCES model (Aumont \& Bopp 2006). This model implemented worldwide the phytoplankton growth model of Geider et al. (1997), and provided C:chl a ratios as a function of latitude, season, and depth, taking into account the influence of $T$, irradiance and nutrient availability. The variable $\mathrm{C}$ :chl a ratio provides a better representation of food availability than a constant ratio, but phytoplankton does not represent the whole range of parti- cles grazed by appendicularians at sea, which also include heterotrophic organisms (i.e. bacteria and microzooplankton) and small organic detritus. Even if appendicularian food in our model should take into account the types, size spectra and quality of potential food particles, the only data available in most cases are chl a concentrations. In such situations, we used chl a as a first order estimator of the available food.

In situ observations in the English Channel. In order to validate model predictions (below) against seasonal successions of appendicularians, we used in situ observations of appendicularians made by López-Urrutia et al. (2005) in the English Channel. Because our model is based on the physiology of organisms, it can only be applied when physiology is the main factor controlling appendicularian succession. In other words, it cannot be used when horizontal transport by currents controls the appendicularian assemblages. We then focussed our study on samples from the L4 site (off Plymouth, UK), which is the only location where a succession involving 3 of the 4 modelled species was observed. 
The organisms were collected weekly with $200 \mu \mathrm{m}$ mesh plankton nets (vertical tows: 0 to $50 \mathrm{~m}$ ) in 1999 and 2000. All appendicularian species were identified and enumerated.

In order to apply our model, we used the $T$ and chl a observed weekly at the same location and during the same period as appendicularians. The data had been sampled weekly using a CTD $\left(T^{\circ} \mathrm{C}\right)$ or a fluorimetric method on water sampled at $10 \mathrm{~m}(\mathrm{chl} \mathrm{a})$. The potential food for appendicularians $\left(\mu \mathrm{C} \mathrm{l}^{-1}\right)$ was estimated from the observed chl $a$ using a seasonally variable $\mathrm{C}: \mathrm{chl} a$ ratio at the corresponding depth and location (PISCES model; see 'Model').

In situ observations from satellite images. In order to apply the model on a larger geographic scale, we used the mean seasonal values (2002 to 2005) of sea surface temperature (SST) and ocean colour derived chl a from the MODIS satellite (OceanColor Web, NASA, http:// oceancolor.gsfc.nasa.gov/). Because the ocean colour images do not include the sub-surface chl a maximum, we estimated the depth and concentration of this chl $a$ maximum following the methodology developed by Morel \& Berthon (1989) as modified by Uitz et al. (2006). The available food concentration $\left(\mu \mathrm{gC} \mathrm{l}^{-1}\right)$ was estimated for each season using the PISCES variable $\mathrm{C}$ :chl $a$ ratio at the depth of the chl a maximum.

In situ observations in the North Atlantic. In situ observations of appendicularians were made in the North Atlantic Ocean during the POMME (Programme Ocean Multidisciplinaire Meso Echelle) research cruises. The study area was located off the Iberian Peninsula (39 to $45^{\circ} \mathrm{N}, 15$ to $21^{\circ} \mathrm{W}$ ). Sampling took place in winter 2001 (POMME 1), spring 2002 (POMME 2) and late summer 2002 (POMME 3). Each cruise consisted of 2 legs: Leg 1 was a spatial survey of the study zone, and Leg 2 focused on selected 'long stations' that were sampled during $48 \mathrm{~h}$.

During Leg 2 of the POMME 3 cruise, the UVP model 4 (UVP4) (Gorsky et al. 2000b) was deployed at 4 stations, where it recorded large numbers of appendicularians. These were not represented in the oblique BIONESS zooplankton tows (0 to $700 \mathrm{~m}$ oblique tows; $500 \mu \mathrm{m}$ mesh size), and were largely undersampled in the vertical WP2 tows ( 0 to $200 \mathrm{~m}$ vertical tows; $200 \mu \mathrm{m}$ mesh size; V. Andersen \& L. Mousseau, pers. comm.).

The UVP recorded information on particles $>100 \mu \mathrm{m}$, i.e. large marine snow and zooplankton. Abundances and size distributions of living and non-living objects were determined down to $1000 \mathrm{~m}$ depth. The UVP4 uses two $54 \mathrm{~W}$ Chadwick Helmuth stroboscopes synchronized with 2 video cameras. The beams are spread into a structured $8 \mathrm{~cm}$ thick slab by 2 mirrors. The particles illuminated in volumes of 1.25 and $10.5 \mathrm{l}$ are recorded simultaneously by the 2 cameras. Appendicularians were counted from the wide-angle camera, which surveys $\sim 120 \mathrm{~m}^{3}$ for a 0 to $1000 \mathrm{~m}$ cast. The short duration of the flashes (pulse duration $=30 \mu \mathrm{s}$ ) allows for a fast lowering speed (up to $1.5 \mathrm{~m} \mathrm{~s}^{-1}$ ) without deteriorating image quality. The 0 to $1000 \mathrm{~m}$ water column was sampled with only minor overlapping between 2 successive images. The images are processed in situ during the recovery of the instrument. The total number of profiles recorded at each station are given in Table 2. All profiles were examined by experts and appendicularians enumerated. For each station, the mean concentration of appendicularians were calculated over $5 \mathrm{~m}$ depth bins.

Additional information was collected with a CTD SBE911 Rosette. Total particulate carbon (TPC) was estimated from bio-optical profiles (spectrophotometer ac-9 WETLabs ${ }^{\circledR}$; Moore 1994) by converting the $555 \mathrm{~nm}$ beam attenuation into TPC using the conversion factor determined during the cruise, compared to water samples filtered through GF/F filters and analysed with a Robobrep Europa Scientific ${ }^{\circledR}$ analyzer (Merien 2003). TPC was used as food concentration in the model. This measurement is probably more representative of the food available to appendicularians than chl $a$, despite the fact that TPC includes large particles that appendicularians cannot filter as well as detritic matter of low nutritional value.

From the in situ observations of abundance, we estimated the effect of filter-feeding appendicularians on the consumption of small particles (e.g. algae, bacteria), the production of large particles (discarded houses, faecal pellets), and the organic matter involved in respiration and growth. We proceeded in 2 steps: firstly, we identified the species having the highest growth rate based on environmental parameters (food concentration in carbon units, $T^{\circ} \mathrm{C}$ ), which we assumed to be the dominant appendicularian species; secondly, we used the model parameterized for that species for the whole life cycle of the appendicularian using the observed environmental conditions in order to estimate the mean daily rates of filtration, growth, respiration, and house and pellet production. We used these individual rates to calculate a resulting rate for the whole population observed at every depth bin at each sampling station.

Table 2. Geographical locations of stations during the POMME 3 Leg 2 cruise, and number of UVP profiles used for appendicularian identification

\begin{tabular}{|llcc|}
\hline Station & Latitude & Longitude & No. of UVP profiles \\
\hline S1 & $40.1^{\circ} \mathrm{N}$ & $18.7^{\circ} \mathrm{W}$ & 3 \\
S2 & $42.2^{\circ} \mathrm{N}$ & $19.83^{\circ} \mathrm{W}$ & 4 \\
S3 & $41.4^{\circ} \mathrm{N}$ & $22.05^{\circ} \mathrm{W}$ & 5 \\
S4 & $42.52^{\circ} \mathrm{N}$ & $17.97^{\circ} \mathrm{W}$ & 4 \\
\hline
\end{tabular}




\section{RESULTS AND DISCUSSION}

\section{Model calibration}

The results of model calibrations on the life cycles of Oikopleura longicauda, O. fusiformis and O. rufescens are presented in Figs. 1 \& 2. The parameter values for each species resulting from the calibration are given in Table 1. Figs.1 \& 2 show that a single model based on a small number of physiological observations (Sato et al. 2003, 2005), and calibrated with species specific sets of parameters is sufficient to simulate each of their life cycles.

Simulations are consistent with observations obtained for the species grown at different $T$ (Figs. $1 \& 2$ ). Growth rates are correctly estimated until the beginning of reproduction (i.e. 1 or $2 \mathrm{~d}$ before the end of the experiment). The length of the life cycle is also cor- rectly reproduced, even if the life span of $O$. longicauda and $O$. rufescens are underestimated at the highest $T$ (Figs. $1 \& 2$ ). This small discrepancy may be due to over-simplified representation of the length of the spawning window in the model, which considers the properties of a single mean individual, whereas in the real population, individual variability exists due notably to the fact that the larger, ripe individuals released their gametes and died before the slowly growing individuals, which reproduce later (Sato et al. 2003). The early spawning of the largest individuals could explain the negligible growth of $O$. rufescens observed at the end of its life cycle (Fig. 2). However, this possible misrepresentation of the life span at high $T$ has no effect on the estimates of growth rate, and only the estimates are used in the following applications.

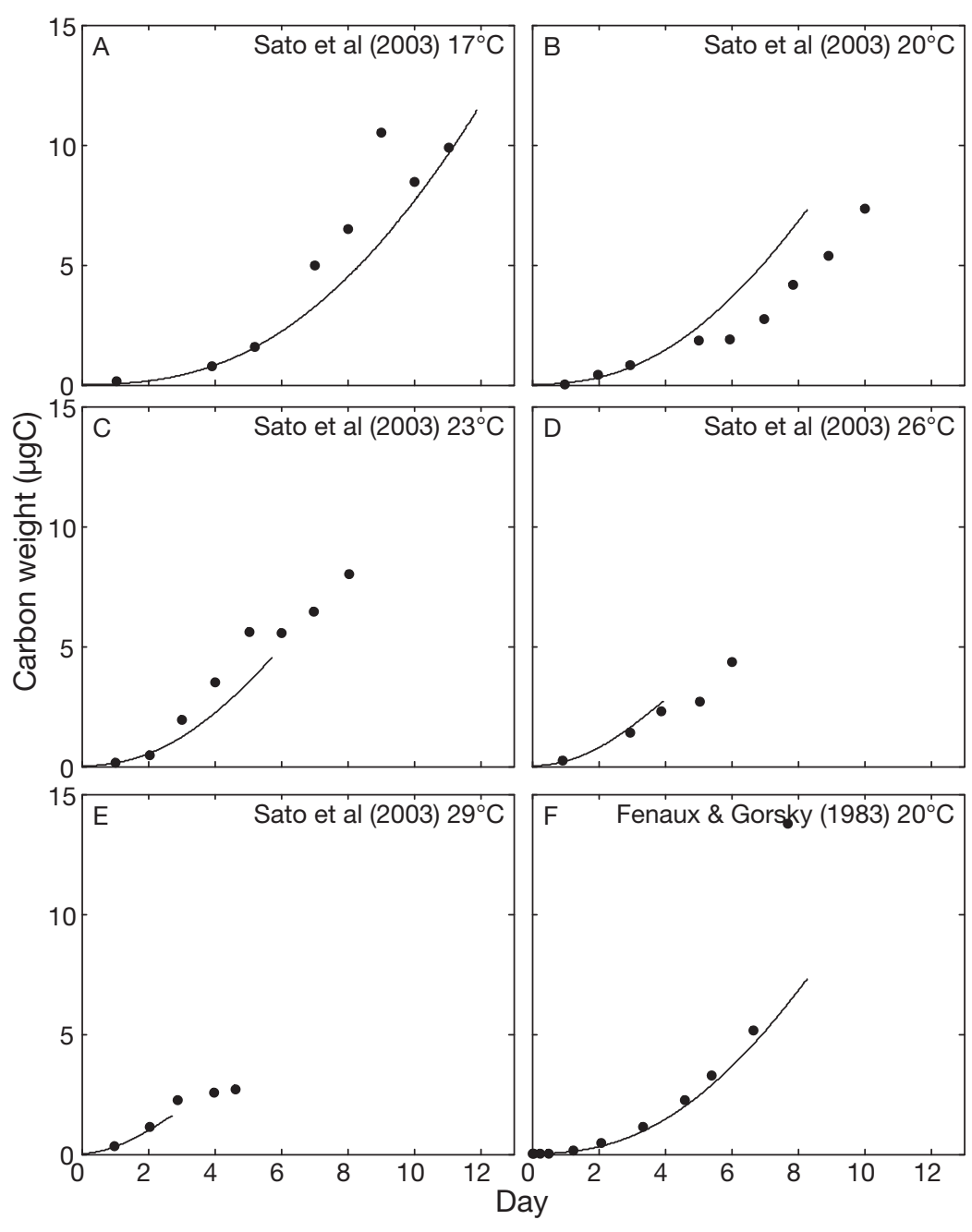

Fig. 1. Oikopleura longicauda. Growth curves at different temperatures. Dots: experimental data from Sato et al. (2003) and Fenaux \& Gorsky (1983). Lines: model simulations

\section{Growth rates and ecological niches}

Over a wide range of stable conditions of food and $T$, the model simulates similar trends of growth rates for the 4 species (i.e. including Oikopleura dioica; Lombard et al. 2009) (Fig. 3) with optimum values observed in mesotrophic conditions and for high $T$ (i.e. 100 to $150 \mu \mathrm{gC} \mathrm{l}^{-1}, T>25^{\circ} \mathrm{C}$ ). Of the 4 species, O. fusiformis shows the highest growth rate under these optimum conditions. Fig. 3 also indicates the environmental conditions that may support positive growth for the different species. Compared to $O$. dioica (Fig. 3A), the other 3 species (Fig. 3B,C,D) seem to have higher growth at high food concentrations. In addition, $O$. longicauda seems to be strongly growth limited at low $T$ (Fig. 3B) and O. rufescens appears only little affected by high food concentrations (Fig. 3D).

The limits within which the growth is positive provide a first indication of the breadth of the fundamental niche according to Levins (1968), who defined the ecological niche as a measure of fitness in a multidimensional space. However, definitions of the fundamental niche may be inappropriate for natural populations because when several species are present, their ecological niches are reduced by competitive exclusion and thus become realized niches 


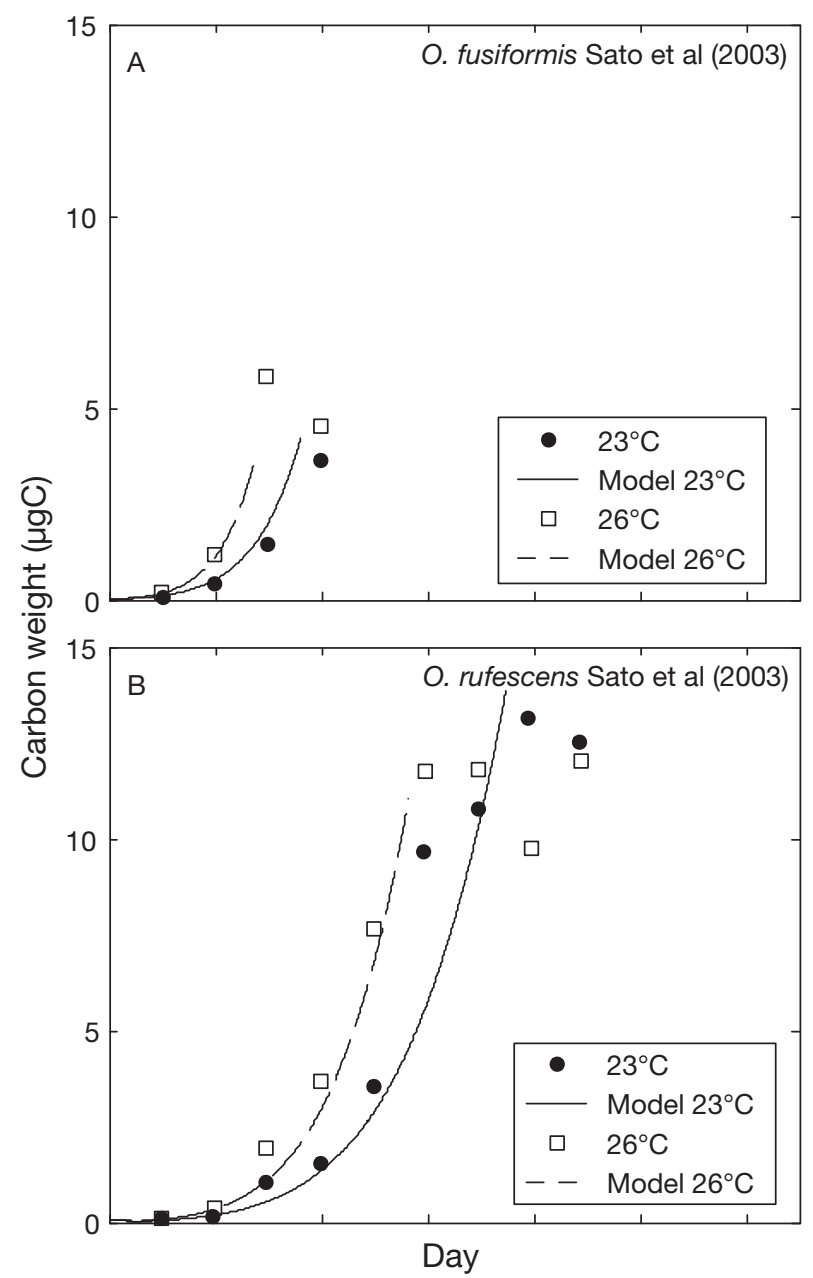

Fig. 2. Oikopleura fusiformis, O. rufescens. Growth of (A) $O$. fusiformis and (B) O. rufescens at different temperature $(T)$. Dots: experimental data from Sato et al. (2003). Lines: model simulations. At 23 and $26^{\circ} \mathrm{C}\left(O\right.$. rufescens) and $26^{\circ} \mathrm{C}$ (O. fusiformis), the last experimental points correspond to the end of reproduction period. As these organisms died after spawning, the population stopped increasing in size (plateau); these points were not used in the model calibration

(Hutchinson 1957). We obtained a simplified estimation of the realized niche breadth for each of the 4 species by comparing their growth rates, and thus determined which species has the highest growth rate under a set of environmental conditions. This approach is implemented in Fig. 4 and is, as far as we know, the first estimation of the realized niches of appendicularian species related to their physiology and growth ability as a function of $T$ and food concentration.

Using this simplified representation of the realized niche of each species, we defined, with due consideration of the limitations of the approach (Hutchinson 1961, Wilson 1990), the environmental conditions within which each species has the highest growth rate and may thus theoretically dominate the assemblage. Fig. 4 shows that Oikopleura dioica does well in low- $T$ $\left(<20^{\circ} \mathrm{C}\right)$ mesotrophic to eutrophic conditions, O. longicauda has higher growth rates than other species in oligotrophic conditions, O. fusiformis is dominant in warm (above $20^{\circ} \mathrm{C}$ ) mesotrophic to eutrophic conditions, and $O$. rufescens shows the highest growth rate in highly eutrophic conditions.

The realized niches in Fig. 4 must be considered with caution, because mortality and predation are not represented in the model. There are also other limitations to these ecological realized niches. Firstly, our study considers 4 appendicularian species only, i.e. it does not take into account other appendicularian species or other groups of organisms. Introduction of other appendicularians in the model, such as the typically cold water species Oikopleura vanhoeffeni, O. labradorensis and Fritilaria borealis, could reduce the breadth of the realized niche of O. dioica, O. longicauda and O. rufescens in cold waters. Similarly, introduction of organisms belonging to other groups such as salps, copepods and fishes, may significantly reduce the realized niche of appendicularians by competition and predation (Sommer et al. 2003, López-Urrutia et al. 2004, Stibor et al. 2004); hence, especially in the case of clearly limiting conditions (i.e. cold water or low food concentration) where appendicularian growth rates are low, the actual limits of the realized ecological niches could be somewhat different from those in Fig. 4. Secondly, the growth rates we estimated originate from model simulations under constant food and $T$ conditions, and may be different in fluctuating environments, e.g. in cases of rapid changes in $T$ (e.g. wind events, currents) or food concentration (e.g. blooms). Given the high growth rates of all appendicularian species in mesotrophic to eutrophic conditions, the one present in the ecosystem under limiting conditions could rapidly respond to increasing food. Hence, it is possible that the composition of the appendicularian assemblage that dominates during a high-food event is influenced by the species response to food-limited conditions prior to the event. Thirdly, our model only takes into consideration $T$ and food concentration, and does not consider other environmental conditions such as salinity. It is known that some appendicularian species can have different behaviour under different salinity conditions (Sato et al. 2001, López-Urrutia et al. 2005), but as the effects of salinity on physiological rates are poorly known, it was preferable to not include them in our model.

Despite these limitations, the realized niches of the 4 species in Fig. 4 are consistent with field observations. Indeed in the ocean, Oikopleura dioica is found in temperate waters, and O. longicauda, O. fusiformis and O. rufescens are common in warm waters (López- 


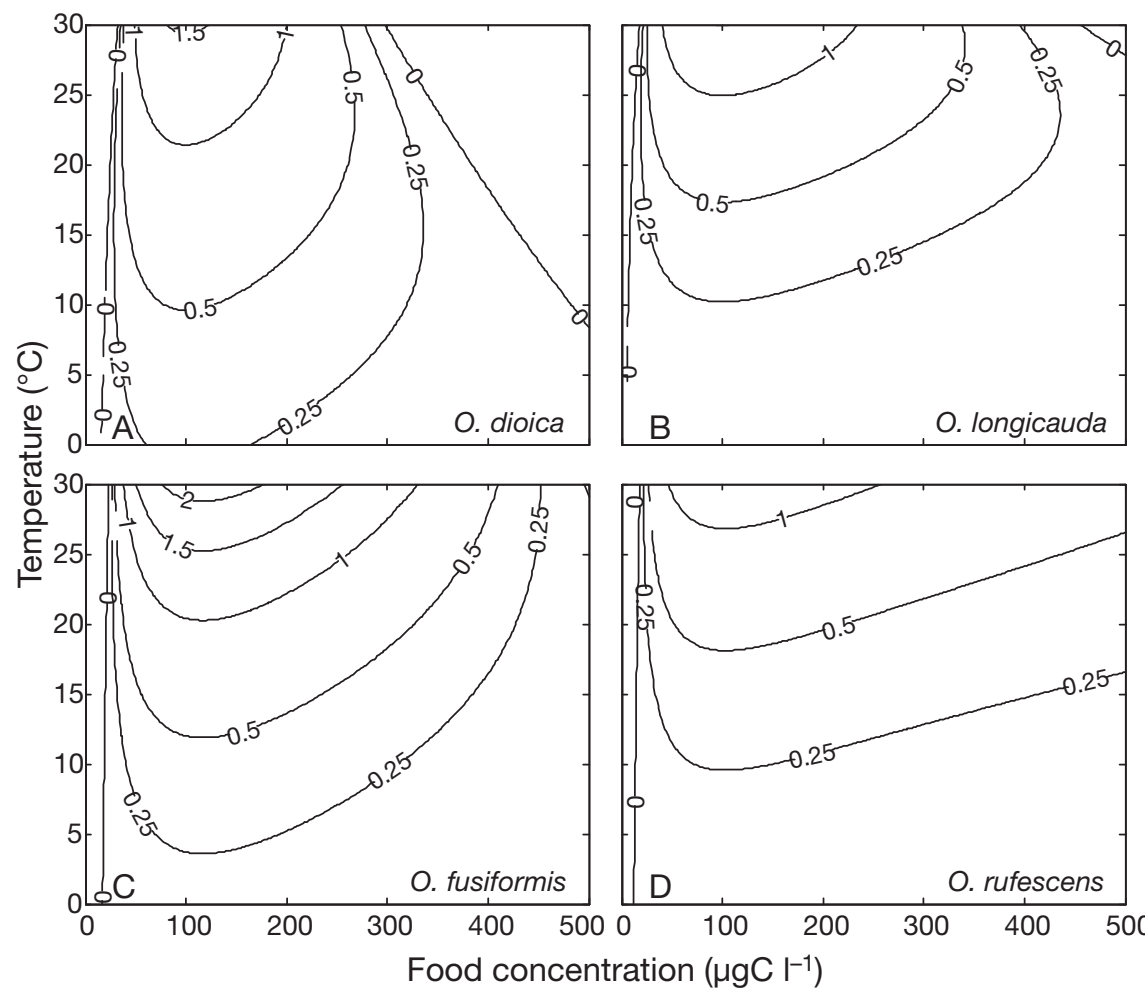

Fig. 3. Oikopleura spp. Daily growth rates $\left(\mathrm{d}^{-1}\right)$ of (A) O. dioica, (B) O. longicauda, (C) O. fusiformis and (D) O. rufescens as a function of temperature and food concentration

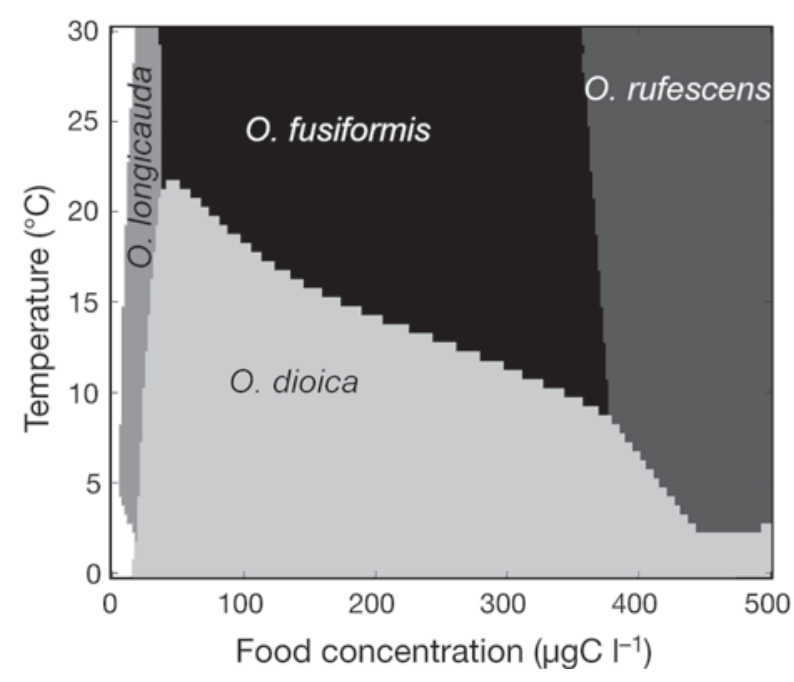

Fig. 4. Oikopleura spp. Realized ecological niches of the 4 appendicularians obtained by comparing their respective growth rates as a function of temperature and food concentration

Urrutia et al. 2005). Moreover, in warm oligotrophic systems, O. longicauda was observed to be dominant, whereas $O$. fusiformis occurred only in small numbers (Scheinberg et al. 2005). It follows that our approach can be used to determine the potentially dominant appendicularian species based on the prevailing $T$ and food concentration observed at sea.

\section{Model validation and application: seasonal species succession}

We validated our realized ecological niche approach by running the model with $T$ and potential food observed in the English Channel during 1999-2000 (López-Urrutia et al. 2005). We compared the succession of dominant species predicted by the model with the observed species composition at sea (Fig. 5). Our model applied to the above 4 appendicularian species predict that Oikopleura dioica would have the highest growth rate nearly during the whole period and would then be the dominant species except in few time intervals. In April 1999, an intense bloom of phytoplankton was recorded during $3 \mathrm{wk}$ (maximum concentration: $9.8 \mathrm{mg} \mathrm{chl} \mathrm{a} \mathrm{m}^{-3}$ ), leading to the prediction of dominance by $O$. rufescens. From the end of July to October 1999, because of warmer conditions combined with higher food concentration, $O$. fusiformis was predicted to be the dominant species in an alternation with O. dioica. In December 1999, low food conditions led the model to estimate that $O$. longicauda could be the dominant species. This predicted seasonal succession is in good agreement with the available observations (López-Urrutia et al. 2005, our Fig. 5). O. dioica was the dominant oikopleurid species nearly all the year. From September to October, with a $\sim 6 \mathrm{wk}$ delay compared to the first appearance predicted by the model, $O$. fusiformis appear to be the dominant species in an alternative way with $O$. dioica. Finally, O. longicauda was dominant from November to December 1999. However, the predicted dominance of $O$. rufescens during 3 wk in April was not observed during the survey.

One potential bias of our approach is that the amount of food available to appendicularians may have been underestimated as it was based only on chl a without including other potential living and non-living food particles. A second limitation is that chl a was only measured at one depth $(10 \mathrm{~m})$. Despite these limitations, the model outputs matched the observations quite well. This indicates that the physiological behaviour of appendicularians as a function of $T$ and food 


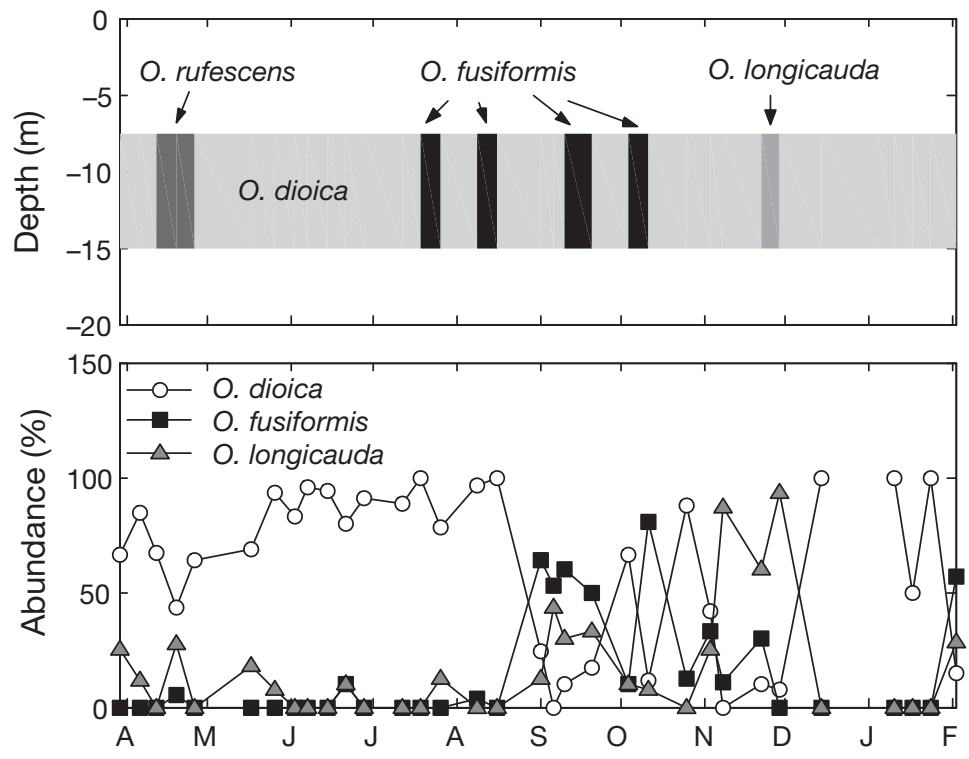

Fig. 5. Oikopleura spp. Seasonal succession of appendicularians in the English Channel (upper panel) predicted by our model based on seasonal variations of temperature and food concentration, and observed dominant species at 0-50 m during 1999-2000 (López-Urrutia et al. 2005, lower panel)

concentration can explain the general pattern of the seasonal succession of appendicularian species.

\section{Model application: ocean-wide biogeography of appendicularians}

Using the global scale data of $T$ and MODIS satellite derived chl $a$, we further used our model to predict the worldwide distributions of dominance (i.e. highest growth rate) among the 4 appendicularian species (Fig. 6). This result is, as far as we know, the first attempt to provide a seasonal description of appendicularians ocean-wide biogeography based on sea surface conditions.

In Fig. 6, Oikopleura dioica is generally dominant in temperate regions and in coastal ecosystems because of its success at $T<20^{\circ} \mathrm{C}$ and in meso-eutrophic conditions (Fig. 4). Our model results in temperate and subtropical conditions are consistent with the reported neritic preference of this species, but the model also suggest that $O$. dioica may also be dominant offshore between 30 and $60^{\circ}$ latitude in the 2 hemispheres, with an even wider latitudinal distribution in the North. Because information on appendicularian species is, to our knowledge, missing in these regions, the hypothesis of dominance by $O$. dioica offshore needs to be tested by sampling. According to the model, O. dioica is also dominant in the coastal upwelling areas of California, Chile, Mauritania and Benguela. The geogra- phic dominance of $O$. dioica is broadest in winter and spring. During summer, the dominance of $O$. dioica is restricted to a narrow zone along coastlines and is replaced offshore by $O$. longicauda. Species $O$. longicauda is especially successful in oligotrophic conditions (Fig. 4), and its widest zone of dominance is from equatorial to temperate regions (Fig. 6); it can grow and dominate the appendicularian assemblage in oligotrophic offshore areas. In winter, this species is dominant in tropical oligotrophic offshore waters. During summer in the centre of the tropical offshore waters, the food concentration becomes so low that it no longer allows this species to grow, and as the offshore subtropical and temperate zones become more oligotrophic, $O$. longicauda replaces $O$. dioica and becomes dominant. Species O. fusiformis is typically successful in warm waters $\left(>20^{\circ} \mathrm{C}\right)$ and in meso- to eutrophic conditions (Fig. 4). As a consequence, it dominates the appendicularian assemblages in upwelling and coastal areas between $20^{\circ} \mathrm{N}$ and $20^{\circ} \mathrm{S}$, and also dominates during summer in coastal temperate regions. Because it is mostly successful in highly eutrophic, warm conditions, O. rufescens dominates the appendicularian assemblage in a few coastal tropical regions only. In tropical offshore ecosystems, the available food does not seem to be sufficient to support the growth of any of the 4 species. These conclusions are limited by the fact that the amount of food calculated by the model is based on in situ chl a concentration, which may have underestimated the total available food. This limitation does not likely cause large discrepancies in mesotrophic and eutrophic conditions, but it could lead to food underestimation in highly oligotrophic conditions where the ratio of phytoplankton carbon to total particulate organic carbon is lower than in richer environments (Legendre \& Michaud 1999, their Eqs. 11 \& 12).

We compared our model predictions (Fig. 6) with the actual dominance of the 4 species at sea (Table 3, 517 field observations). The results of comparison are (1) model predictions matched $71 \%$ of the observations, (2) the dominant species was incorrectly predicted in only $16 \%$ of cases, and (3) in $13 \%$ of cases, the model predicted that none of the species could grow where Oikopleura longicauda was actually recorded. The observed differences between model predictions and observations, such as the prediction of dominance by O. longicauda instead of O. fusiformis in South European seas during summer and autumn, or the actual dominance of $O$. longicauda in the central Indian Ocean where the model predicted no appendic- 

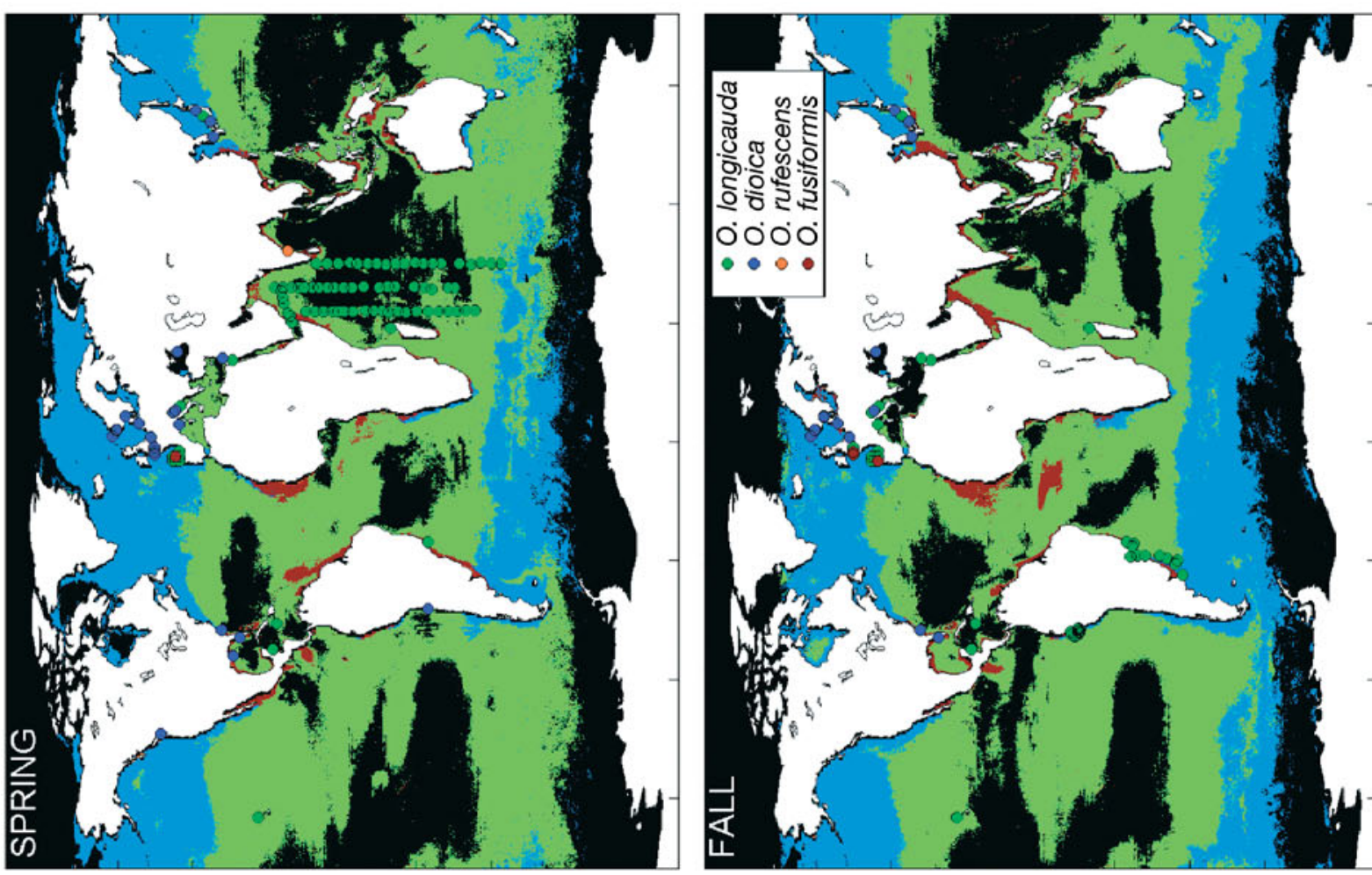

वี
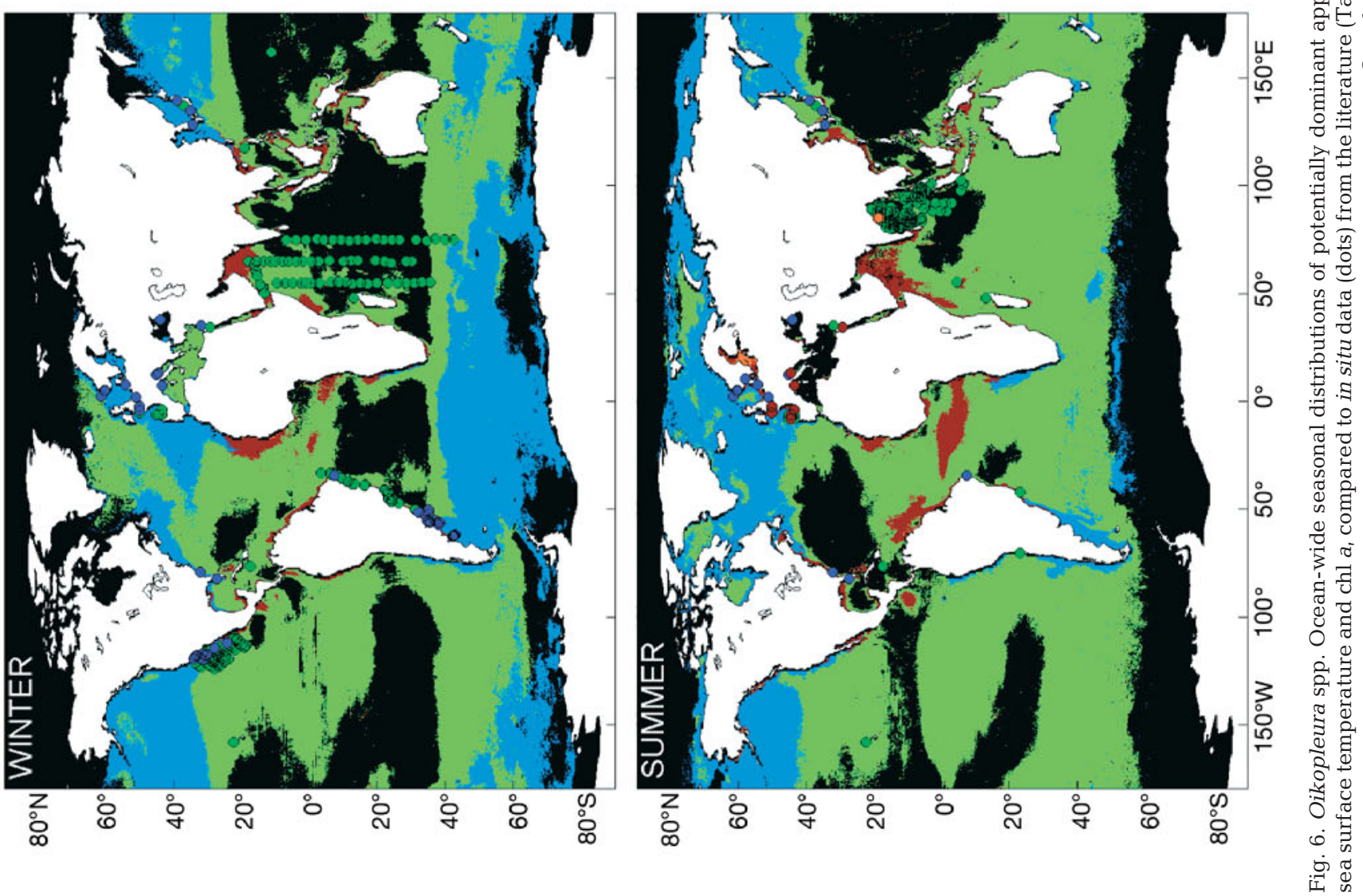
Table 3. Observations of appendicularian species composition in the World Ocean: location, sampling season (Sp: spring; Su: summer; F: fall; W: winter; All: all seasons; An. Mean: annual mean), number of observations (n) and source

\begin{tabular}{|c|c|c|c|c|c|c|c|}
\hline Location & $\begin{array}{l}\text { Sampling } \\
\text { season }\end{array}$ & $\mathrm{n}$ & Source & Location & $\begin{array}{l}\text { Sampling } \\
\text { season }\end{array}$ & $\mathrm{n}$ & Source \\
\hline \multicolumn{4}{|l|}{ Atlantic Ocean } & \multicolumn{4}{|l|}{ Pacific Ocean } \\
\hline Norwegian fjord & All & 4 & López-Urrutia et al. (2005) & \multicolumn{2}{|c|}{ Orcas Island (WA) Sp } & 1 & Hansen et al. (1996) \\
\hline Norwegian fjord & All & 4 & López-Urrutia et al. (2005) & \multicolumn{2}{|c|}{ California $\quad$ W } & 1 & Landry et al. (1994) \\
\hline Norwegian fjord & All & 4 & López-Urrutia et al. (2005) & California & $\mathrm{W}$ & 1 & Passow et al. (2001) \\
\hline Swedish fjord & Sp \& F & 2 & Vargas et al. (2002) & California coast & W & 83 & Fenaux \& Dallot (1980) \\
\hline Skagerrak & $\mathrm{Su} \& \mathrm{~F}$ & 2 & Maar et al. (2004) & \multicolumn{2}{|c|}{ Inland Sea of Japan All } & 4 & Uye \& Ichino (1995) \\
\hline North Sea & An. Mean & 4 & Le Fevre-Lehoerff et a & \multicolumn{2}{|c|}{ Central Japan All } & 4 & Itoh (1990) \\
\hline (1995) & & & & \multicolumn{2}{|c|}{ Southern Japan Sea All } & 4 & Tomita et al. (2003) \\
\hline North Sea & All & 4 & Greve (2005) & \multicolumn{2}{|c|}{ Tokyo Bay All } & 4 & Nomura \& Murano (1992) \\
\hline English Channel & All & 4 & Acuña et al. (1995) & Korea & All & 4 & Lee et al. (2001) \\
\hline English Channel & All & 4 & López-Urrutia et al. (2005) & South China Sea & W & 1 & Yang \& Wang (1988) \\
\hline Cantabrian Sea & All & 4 & Acuña \& Anadon (1992) & & c) $\quad \mathrm{W}$ & 1 & Gerber \& Marshall (1974) \\
\hline Cantabrian Sea & $\mathrm{Su}$ & 36 & Acuña (1994) & $\begin{array}{l}\text { Eniwetok (Pacific) } \\
\text { Hawaii }\end{array}$ & $\mathrm{W} \& \mathrm{Sp}$ & 2 & Scheinberg et al. (2005) \\
\hline Cantabrian Sea & All & 16 & López-Urrutia et al. (2003) & \multirow{2}{*}{$\begin{array}{l}\text { Hawaii } \\
\text { Peru }\end{array}$} & An. Mean & 4 & Tagushi (1982) \\
\hline Cantabrian Sea & All & 12 & López-Urrutia et al. (2005) & & $\mathrm{F}$ & 12 & Fenaux (1968) \\
\hline South Carolina & All & 4 & Costello \& Stancyk (1983) & \multirow{2}{*}{ Northern Chile } & $\mathrm{Su} \& \mathrm{Sp}$ & 2 & \multirow{2}{*}{ Vargas \& González (2004) } \\
\hline Mississipi plume & $\mathrm{Sp}$ & 1 & Dagg et al. (1996) & & & & \\
\hline Florida & All & 4 & Hopkins (1977) & \multicolumn{2}{|l|}{ Indian Ocean } & & \multirow[b]{2}{*}{ Fenaux (1969a) } \\
\hline Jamaica & All & 4 & Hopcroft \& Roff (1998) & \multirow{2}{*}{$\begin{array}{l}\text { Bay of Bengal } \\
\text { Bay of Bengal }\end{array}$} & \multirow{2}{*}{$\begin{array}{l}\mathrm{Su} \\
\mathrm{Sp}\end{array}$} & 89 & \\
\hline Caribbean Sea & $\mathrm{Sp} \& \mathrm{~F}$ & 2 & Osorio (2003) & & & 1 & Madhupratap \\
\hline Northeastern & $\mathrm{W} \& \mathrm{Su}$ & 2 & Silva et al. (2003) & & \multirow{3}{*}{$\mathrm{Su}$} & \multirow{3}{*}{18} & et al. (1980) \\
\hline Brazil & & & & \multirow[t]{2}{*}{ Bay of Bengal } & & & \multirow{2}{*}{ Sreekumaran Nair et al. } \\
\hline Brazil $\quad A$ & An. Mean & 4 & Valentin et al. (1987) & & & & \\
\hline S America coast & $\mathrm{F}$ & 45 & Fenaux (1967) & Indian Ocean & W-Sp & 67 & Fenaux (1972b) \\
\hline Argentina & W & 5 & Capitanio \& Esnal (1998) & Madagascar & All & 4 & Fenaux (1969b) \\
\hline S-W Atlantic Oce & ean $F$ & 12 & Esnal \& Castro (1977) & Seychelles & $\mathrm{Su}$ & 1 & Fenaux (1980) \\
\hline Mediterranean Se & & & & Black Sea & An. Mean & 4 & Shiganova (2005) \\
\hline Adriatic Sea & All & 4 & Fenaux (1972a) & & & & \\
\hline Adriatic Sea & $\mathrm{Sp}$ & 1 & Skaramuca (1977) & Red Sea & & & \\
\hline Venice & All & 4 & Brunetti et al. (1990) & Gulf of Aqaba & $\mathrm{Su}$ & 1 & Vaissiere \& Seguin (1984) \\
\hline Ligurian Sea & All & 4 & Fenaux (1961) & Gulf of Elat & All & 4 & Fenaux (1979) \\
\hline Ligurian Sea & All & 4 & López-Urrutia et al. (2005) & & & & \\
\hline
\end{tabular}

ularian growth, are probably related to underestimation of real food concentration when taking phytoplankton as the only potential food. Despite this limitation, the model generally predicted correctly the most probable dominant appendicularian species in various offshore and inshore systems, from $T$ and food concentration. Our model provides an approach for including appendicularians in ecological-biogeochemical models that consider plankton functional types.

\section{Model application: role of appendicularians in downward carbon flux}

During the POMME 3-Leg 2 cruise in the North Atlantic, large numbers of appendicularians were observed with the UVP at Sites 1 (S1) and 4 (S4), with maximum concentrations of 85 and 135 ind. $\mathrm{m}^{-3}$ at 65 and $70 \mathrm{~m}$, respectively (Fig. 7). In contrast, few appendicularians were observed at Sites 2 (S2) and 3 (S3), where the maximum abundance were 2 and 11 ind. $\mathrm{m}^{-3}$, respectively. Moreover, the UVP continuous records at depth showed that appendicularians were mostly concentrated near the maximum TPC concentration, below the thermocline. The observed numbers of appendicularians were low compared to some coastal regions were they can exceed 10000 ind. $\mathrm{m}^{-3}$ (Taguchi 1982, Ashjian et al. 1997, Hopcroft \& Roff 1998, Fernández \& Acuña 2003, Maar et al. 2004, Scheinberg et al. 2005). This is consistent with the fact that appendicularians generally bloom in mesotrophic or eutrophic coastal conditions, whereas the POMME 3 observations were made in offshore oligotrophic conditions.

The data on the vertical distribution of appendicularians abundance and on T and TPC were used to determine the species with the highest potential growth rate. Our model predicted that Oikopleura dioica was the best candidate for the whole sampling area (except for the upper $25 \mathrm{~m}$ at $\mathrm{S} 1$ where $O$. fusiformis was pre- 

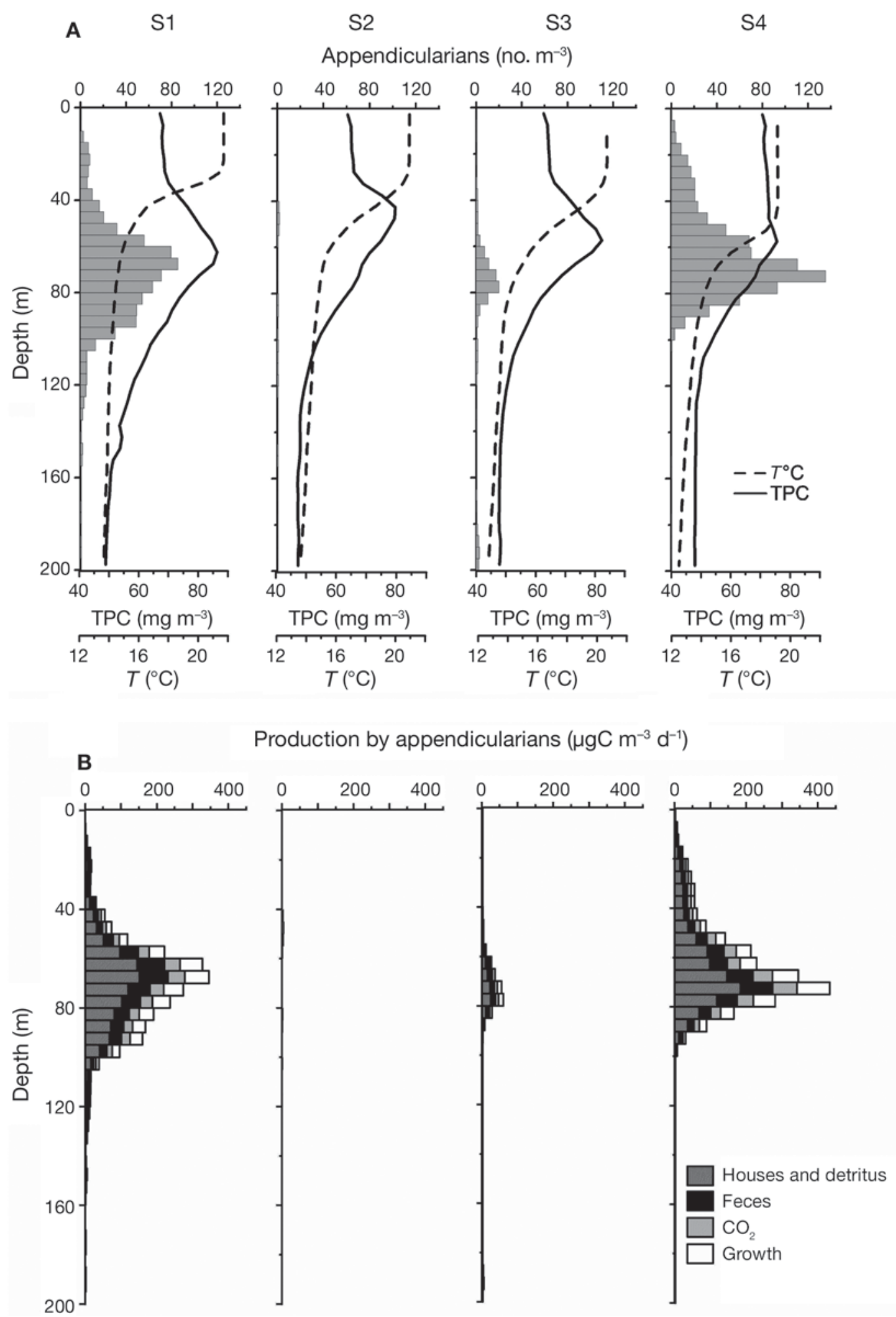

Fig. 7. Oikopleura spp. Vertical distributions of observed and modelled variables at 4 sampling sites during the POMME 3 Leg 2 cruise in the North Atlantic in 2001. (A) Observations: appendicularians recorded with the UVP (grey bars), total particulate carbon estimated from bio-optical profiles (TPC, solid lines) and temperature ( $T$, dashed lines). (B) Modelled daily production of appendicularian detritus (faecal pellets and discarded houses with food particles trapped inside), body mass and $\mathrm{CO}_{2}$ (respiration). The amount of small particles filtered by appendicularians is the sum of the different production estimates 
dicted to be the dominant species). Consequently, we hypothesized that $O$. dioica was the main appendicularian species in the POMME area in late summer 2001. This output of the model was confirmed by direct identification of appendicularian houses on the UVP profiles, and from WP2 net samples where most appendicularians were O. dioica. On the basis of appendicularian abundances and environmental conditions, we simulated the whole life cycle of $O$. dioica in order to estimate their daily effect on the consumption and aggregation of particulate matter and the fluxes of biogenic carbon (Fig. 7). Because appendicularians are present in largest numbers below the thermocline, their impact on carbon fluxes should also be greatest there. Appendicularians in the POMME area had a relatively small effect on TPC consumption (sum of respiration, growth, faecal palettes and discarded houses productions, Fig. 7), i.e. only $0.6 \%$ of the total stock of TPC was grazed daily by appendicularians at the station and depth were their concentration was highest (S4, $70 \mathrm{~m})$. The TPC consumed was used with low efficiency by appendicularians for growth, i.e. at the depth of maximum appendicularian concentration, $65 \%$ of the TPC grazed was lost in the form of large aggregates (i.e. discarded houses and faecal pellets), $14 \%$ was remineralised through respiration and only $21 \%$ was used for growth. As the aggregates are generally produced by appendicularians mostly under the thermocline and have sinking rates of 50 to $120 \mathrm{~m} \mathrm{~d}^{-1}$ (Gorsky et al. 1984a, Alldredge 2005, Dagg \& Brown 2005), they can reach a depth of $200 \mathrm{~m}$ within 1 to $3 \mathrm{~d}$ in low turbulence conditions. Hence, we could compare the production of aggregates by appendicularians with the total flux of particulate organic carbon (POC) from sediment traps moored at $200 \mathrm{~m}$ (Fig. 8). Fig. 8 shows that the amount of sinking matter sampled at $200 \mathrm{~m}$ did not correspond to the production of aggregates by appendicularians, i.e. the latter was lower than the sediment trap flux at S2 and S3, and higher at $\mathrm{S} 1$ and $\mathrm{S} 4$. The low production at S2 and S3 reflects the low concentrations of appendicularians. The situation at $\mathrm{S} 1$ and $\mathrm{S} 4$ requires further discussion.

Our study is not the first to predict a production of particulate matter by appendicularians that exceeds the observed total sinking flux, e.g. in the literature, calculated production of discarded houses represented only 12 to $83 \%$ of the total POC flux in sediment traps at depths $<200 \mathrm{~m}$ (Alldredge 2005), and the flux of faecal pellets did exceed the total POC flux at 25 and $\sim 300 \mathrm{~m}$ depths (Dagg \& Brown 2005, Deibel et al. 2005). The difference between simulated aggregate production and the observed flux in traps may reflect the relatively low efficiency of sediment traps, as observed during the POMME cruise for traps at $400 \mathrm{~m}$ (19 to $53 \%$ efficiency measured using thorium-230 iso-

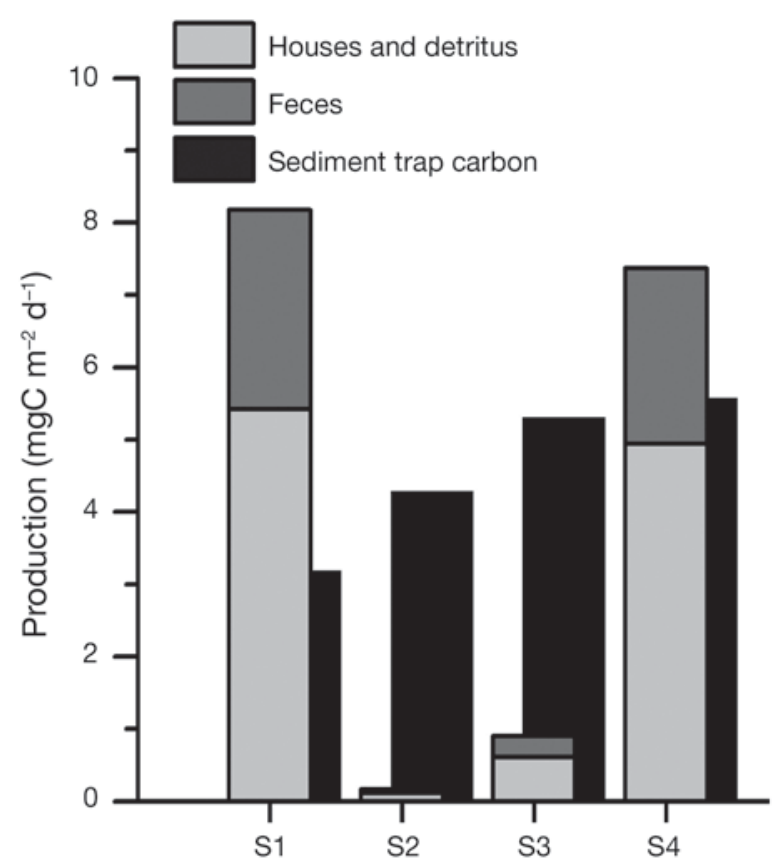

Fig. 8. Oikopleura spp. Comparison of the integrated production of detritus by appendicularians (faecal pellets and discarded houses with food particles trapped inside) estimated from our model with the observed particulate organic carbon flux in sediment traps at $200 \mathrm{~m}$

tope; Guieu et al. 2005). Indeed, discarded houses are sticky and may potentially have a different trapping efficiency compared to other material (faecal pellets). In addition, visual determination of particles collected in the traps showed that appendicularian detritus made up only a small fraction of the total. Hence, the difference between our model estimates of particulate matter produced by appendicularians and the flux of matter in sediment traps may also be due to rapid degradation or consumption of appendicularian aggregates above the depths of traps. There is evidence from other studies for these 2 effects, as discussed next.

Observations in a Swedish fjord showed that in sediment traps located at different depths, $70 \%$ of the discarded houses observed at $10 \mathrm{~m}$ disappeared between 10 and $30 \mathrm{~m}$ (Vargas et al. 2002). The POMME 3 cruise was undertaken at the end of the summer oligotrophic phase, when phytoplankton were largely dominated by pico- and nanophytoplankton (Claustre et al. 2005) and appendicularian faecal pellets would mainly contain this type of plankton. Hansen et al. (1996a) showed that the faecal pellets of Acartia tonsa eating a nanoflagellate algal diet were more rapidly degraded by bacteria than those from a diatom diet, and lost more than $50 \%$ of their volume in only $9 \mathrm{~h}$. In the case of thaliacean faecal pellets (in situ sampling), a 50\% decrease in carbon 
content was observed within $30 \mathrm{~h}$ due to bacterial activity (Pomeroy et al. 1984). Hence, during the transit down to $200 \mathrm{~m}$, a large fraction of the appendicularian faecal pellets could have been degraded by bacteria. The same might have applied to discarded houses, but their degradation rate is unknown and may be enhanced by the microbial community, including ciliates, present in the food concentrating filters (Davoll \& Silver 1986, Hansen et al. 1996b).

In addition to degradation, the aggregates, including freshly filtered particles in the houses and only partially digested organic matter in the faecal pellets, can be grazed upon by a large number of zooplankton species during the oligotrophic period. For example, cyclopoid copepods belonging to the genus Oithona are known to be coprophagous (Gonzáles \& Smetacek 1994), and coprorhexy has been observed for several calanoid copepods (Lampitt et al. 1990). In addition, copepods of the genera Oncaea and Calanus and euphausiids can all feed intensively on discarded houses (Alldredge 1972, 1976, Dagg 1993, Ohtsuka et al. 1993, Dilling et al. 1998). All these taxonomic groups were present during the POMME cruise (V. Andersen \& L. Mousseau, pers. comm.) Hence, the aggregates produced by appendicularians could have been partly recycled by the food web instead of being exported to the deeper waters.

\section{CONCLUSIONS}

From the conditions of $T$ and food concentration existing in different oceanic environments, a physiological model was used to estimate the realized niches of 4 appendicularian species, predict their seasonal succession, provide a seasonal ocean-wide biogeography of their distribution, and compare their predicted production of aggregates with the flux of POC within sediment traps. It was shown that this model can provide first-order estimates of the most probably present appendicularian species. The next stage of model development would be to include the biology of populations, which would take into account niche overlaps of the different species, simulating the effect of a fluctuating environment and the abundance of the different appendicularian species. However, most population biology processes (i.e. predation on appendicularians, mortality and fecundity) are still poorly documented at sea and thus need focussed research. Another improvement of the model would be the inclusion of key processes of degradation/consumption of the particles produced by appendicularians in order to estimate particle changes during their downward transit. However, most of these processes are not presently known under field conditions.
Acknowledgements. We thank A. Lopez for providing the data from the English Channel, L. Bopp for providing outputs of the PISCES model, and P. Nival, D. Deibel, J. L. Acuña, C. Poggiale, F. Carlotti, L. Stemmann and E. Urban for constructive discussions. We thank the 4 anonymous reviewers for their constructive comments that allowed us to improve the manuscript. We also thank the EC FP6 SESAME project Contract No. GOCE-2006-036949, the French ZOOPNEC program, the MARBEF, EUR-OCEANS European Networks of Excellence and the Marie Curie Intra-European Fellowship No. 221696 for financial support.

\section{LITERATURE CITED}

Acuña JL (1994) Summer vertical distribution of appendicularians in the Central Cantabrian Sea (Bay of Biscay). J Mar Biol Assoc UK 74:585-601

Acuña JL, Anadon R (1992) Appendicularian assemblages in a shelf area and their relationship with temperature. J Plankton Res 14:1233-1250

Acuña JL, Bedo AW, Harris RP, Anadon R (1995) The seasonal succession of appendicularians (Tunicata: Appendicularia) off Plymouth. J Mar Biol Assoc UK 75:755-758

Alldredge AL (1972) Abandoned larvacean houses: a unique food source in the pelagic environment. Science 177: 885-887

Alldredge AL (1976) Discarded appendicularian houses as sources of food, surface habitats, and particulate organic mater in planktonic environments. Limnol Oceanogr 21: $14-23$

Alldredge AL (2005) The contribution of discarded appendicularian houses to the flux of particulate organic carbon from oceanic surface waters. In: Gorsky G, Youngbluth MJ, Deibel D (eds) Response of marine ecosystems to global change: ecological impact of appendicularians. GB Scientific Publisher, Paris, p 309-326

> Ashjian C, Smith S, Bignami F, Hopkins T, Lane P (1997) Distribution of zooplankton in the Northeast Water Polynya during summer 1992. J Mar Syst 10:279-298

Aumont O, Bopp L (2006) Globalizing results from ocean in situ iron fertilization studies. Global Biogeochem Cycles 20, GB2017, doi:10.1029/2005GB002591

Benfield MC, Davis CS, Wiebe PH, Gallager SM, Lough RG, Copley NJ (1996) Video plankton recorder estimates of copepod, pteropod and larvacean distributions from a stratified region of Georges Bank with comparative measurements from a MOCNESS sampler. Deep-Sea Res II 43: 1925-1945

Brunetti R, Baiocchi L, Bressan M (1990) Seasonal distribution of Oikopleura (Larvacea) in the lagoon of Venice. Boll Zool 57:89-94

Capitanio FL, Esnal GB (1998) Vertical distribution of maturity stages of Oikopleura dioica (Tunicata, Appendicularia) in the frontal system off Valdes Peninsula, Argentina. Bull Mar Sci 63:531-539

Claustre H, Babin M, Merien D, Ras J and others (2005) Toward a taxon-specific parameterization of bio-optical models of primary production: a case study in the North Atlantic. J Geophys Res 110, C07S12, doi:10.1029/ 2004JC002634

Costello J, Stancyk SE (1983) Tidal influence upon appendicularian abundance in North Inlet estuary, South Carolina. J Plankton Res 5:263-277

Dagg MJ (1993) Sinking particles as a possible source of nutrition for the copepod Neocalanus cristatus in the subarctic Pacific Ocean. Deep-Sea Res I 40:1431-1445 
Dagg MJ, Brown SL (2005) The potential contribution of fecal pellets from the larvacean Oikopleura dioica to vertical flux of carbon in a river dominated coastal margin. In: Gorsky G, Youngbluth MJ, Deibel D (eds) Response of marine ecosystems to global change: ecological impact of appendicularians. GB Scientific Publisher, Paris, p 293-308

$>$ Dagg MJ, Green EP, McKee BA, Ortner PB (1996) Biological removal of fine-grained lithogenic particles from a large river plume. J Mar Res 54:149-160

Davis CS, Gallager SM, Berman MS, Haury LR, Strickler JR (1992) The video plankton recorder (VPR): design and initial results. Arch Hydrobiol: Ergeb Limnol 36:67-81

Davoll PJ, Silver MW (1986) Marine snow aggregates: life history sequence and microbial community of abandoned larvacean houses from Monterey Bay, California. Mar Ecol Prog Ser 33:111-120

Deibel D, Saunders PA, Acuña JL, Bochdansky AB, Shiga N, Rivkin RB (2005) The role of appendicularian tunicates in the biogenic carbon cycles of three Arctic polynyas. In: Gorsky G, Youngbluth MJ, Deibel D (eds) Response of marine ecosystems to global change: ecological impact of appendicularians. GB Scientific Publisher, Paris, p 327-356

Dennett MR, Caron DA, Michaels AF, Gallager SM, Davis CS (2002) Video plankton recorder reveals high abundances of colonial Radiolaria in surface waters of the central North Pacific. J Plankton Res 24:797-805

Dilling L, Wilson J, Steinberg D, Alldredge A (1998) Feeding by the euphausiid Euphausia pacifica and the copepod Calanus pacificus on marine snow. Mar Ecol Prog Ser 170:189-201

Esnal GB, Castro RJ (1977) Distributional and biometrical study of appendicularians from the west South Atlantic Ocean. Hydrobiologia 56:241-246

Fenaux R (1961) Existence d'un ordre cyclique d'abondance relative maximale chez les Appendiculaires de surface (Tuniciers pélagiques). CR Hebd Seances Acad Sci Paris 253:2271-2273

Fenaux R (1967) Campagne de la Calypso au large des cotes Atlantiques de l'Amérique du Sud (1961-1962). Première partie. 5. Appendiculaires. Ann Inst Oceanogr 45:33-46

Fenaux R (1968) Algunas apendicularias de la costa Peruana. Bol Inst Mar Peru 9:536-552

Fenaux R (1969a) Les appendiculaires du golfe du Bengale. Mar Biol 2:252-263

Fenaux R (1969b) Les appendiculaires de Madagascar (région de Nosy-Bé). Variations saisonnières. Cah ORSTOM Ser Oceanogr 7:29-37

Fenaux R (1972a) Variations saisonnières des appendiculaires de la region nord Adriatique. Mar Biol 16:310-319

Fenaux R (1972b) Les appendiculaires de la partie centrale de l'océan Indien. J Mar Biol Assoc India 14:496-511

Fenaux R (1976) Cycle vital d'un appendiculaire Oikopleura dioica Fol, 1872 description et chronologie. Ann Inst Oceanogr 52:89-101

Fenaux R (1979) Preliminary data on ecology of appendicularians in Gulf of Elat. Isr J Zool 28:177-192

Fenaux R (1980) Les appendiculaires des Séchelles. Composition de la population. Etudes biométriques des espèces principales. Rev Zool Afr 94:795-806

Fenaux R (1986) Influence de la maille du fillet sur l'estimation des populations d'appendiculaires in situ. Rapp PV Reun Comm Int Explor Sci Mer Mediterr 30:203-204

Fenaux R, Dallot S (1980) Répartition des appendiculaires au large des côtes de Californie. J Plankton Res 2:145-167

Fenaux R, Gorsky G (1983) Cycle vital et croissance de l'appendiculaire Oikopleura longicauda (Vogt), 1854. Ann Inst Oceanogr 59:107-116
Fenaux R, Palazzoli I (1979) Estimation in situ d'une population d'Oikopleura longicauda (Appendicularia) à l'aide de deux filets de maille différente. Mar Biol 55:197-200

Fenaux R, Bone Q, Deibel D (1998) Appendicularian distribution and zoogeography. In: Bone Q (ed) The biology of pelagic tunicates. Oxford University Press, Oxford, p 251-264

Fernández D, Acuña JL (2003) Enhancement of marine phytoplankton blooms by appendicularian grazers. Limnol Oceanogr 48:587-593

Fernández D, López-Urrutia A, Fernández A, Acuña JL, Harris R (2004) Retention efficiency of 0.2 to $6 \mu \mathrm{m}$ particles by the appendicularians Oikopleura dioica and Fritillaria borealis. Mar Ecol Prog Ser 266:89-101

Flood PR (2005) Toward a photographic atlas on special taxonomic characters of oikopleurid Appendicularian (Tunicata). In: Gorsky G, Youngbluth MJ, Deibel D (eds) Response of marine ecosystems to global change: ecological impact of appendicularians. GB Scientific Publisher, Paris, p 59-85

- Flynn KJ, Davidson K, Leftley JW (1994) Carbon-nitrogen relations at whole-cell and free-amino-acid levels during batch growth of Isochrysis galbana (Prymnesiophyceae) under conditions of alternating light and dark. Mar Biol 118:229-237

Gallienne CP, Robins DB (2001) Is Oithona the most important copepod in the world's oceans? J Plankton Res 23: 1421-1432

Geider RJ, MacIntyre HL, Kana TM (1997) Dynamic model of phytoplankton growth and acclimation: responses of the balanced growth rate and the chlorophyll a:carbon ratio to light, nutrient-limitation and temperature. Mar Ecol Prog Ser 148:187-200

Gerber RP, Marshall N (1974) Ingestion of detritus by the lagoon pelagic community at Eniwetok Atoll. Limnol Oceanogr 19:815-824

- González HE, Smetacek V (1994) The possible role of the cyclopoid copepod Oithona in retarding vertical flux of zooplankton faecal material. Mar Ecol Prog Ser 113: 233-246

Gorsky G, Fenaux R (1998) The role of Appendicularia in marine food webs. In: Bone $\mathrm{Q}$ (ed) The Biology of Pelagic Tunicates. Oxford University Press, Oxford, p 161-169

Gorsky G, Fisher NS, Fowler SW (1984a) Biogenic debris from the pelagic tunicate, Oikopleura dioica, and its role in the vertical transfer of a transuranium element. Estuar Coast Shelf Sci 18:13-23

Gorsky G, Palazzoli I, Fenaux R (1984b) Premières données sur la respiration des appendiculaires (tuniciers pélagiques). CR Hebd Seances Acad Sci 298:531-534

Gorsky G, Aldorf C, Kage M, Picheral M, Garcia Y, Favole J (1992) Vertical distribution of suspended aggregates determined by a new underwater video profiler. Ann Inst Oceanogr 68:275-280

Gorsky G, Flood PR, Youngbluth M, Picheral M, Grisoni JM (2000a) Zooplankton distribution in four western Norwegian fjords. Estuar Coast Shelf Sci 50:129-135

Gorsky G, Picheral M, Stemmann L (2000b) Use of the Underwater Video Profiler for the study of aggregate dynamics in the North Mediterranean. Estuar Coast Shelf Sci 50:121-128

Greve W (2005) Biometeorology of North Sea appendicularians. In: Gorsky G, Youngbluth MJ, Deibel D (eds) Response of marine ecosystems to global change: ecological impact of appendicularians. GB Scientific Publisher, Paris, p 277-290 
Guieu C, Roy-Barman M, Leblond N, Jeandel C and others (2005) Vertical particle flux in the northeast Atlantic Ocean (POMME experiment). J Geophys Res 110, C07S18, doi:10.1029/2004JC002672

Halliday NC, Coombs SH, Smith C (2001) A comparison of LHPR and OPC data from vertical distribution sampling of zooplankton in a Norwegian fjord. Sarsia 86:87-99

Hansen B, Fotel FL, Jensen NJ, Madsen SD (1996a) Bacteria associated with a marine planktonic copepod in culture. II. Degradation of fecal pellets produced on a diatom, a nanoflagellate or a dinoflagellate diet. J Plankton Res 18: 275-288

Hansen JLS, Kiørboe T, Alldredge AL (1996b) Marine snow derived from abandoned larvacean houses: sinking rates, particle content and mechanisms of aggregate formation. Mar Ecol Prog Ser 141:205-215

Hopcroft RR, Roff JC (1995) Zooplankton growth rates: extraordinary production by the larvacean Oikopleura dioica in tropical waters. J Plankton Res 17:205-220

Hopcroft RR, Roff JC (1998) Production of tropical larvaceans in Kingston Harbour, Jamaica: Are we ignoring an important secondary producer? J Plankton Res 20:557-569

> Hopcroft RR, Roff JC, Chavez F (2001) Size paradigms in copepod communities: a re-examination. Hydrobiologia 453:133-141

Hopkins TL (1977) Zooplankton distribution in surface waters of Tampa Bay, Florida. Bull Mar Sci 27:467-478

Hutchinson GE (1957) Concluding remarks. Cold Spring Harb Symp Quant Biol 22:415-427

$>$ Hutchinson GE (1961) The paradox of the plankton. Am Nat 95:137-145

Itoh $H$ (1990) Seasonal variation of appendicularian fauna off Miho Peninsula, Suruga Bay, central Japan. Bull Plankton Soc Japan 36:111-119

Lampitt RS, Noji T, von Bodungen B (1990) What happens to zooplankton faecal pellets? Implication for material flux. Mar Biol 104:15-23

Landry MR, Peterson WK, Fagerness VL (1994) Mesozooplankton grazing in the Southern California Bight. I. Population abundances and gut pigment contents. Mar Ecol Prog Ser 115:55-71

Le Fevre-Lehoerff G, Ibanez F, Poniz P, Fromentin JM (1995) Hydroclimatic relationships with planktonic time series from 1975 to 1992 in the North Sea off Gravelines, France. Mar Ecol Prog Ser 129:269-281

Lee JH, Chae J, Kim WR, Jung SW, Kim JM (2001) Seasonal variation of phytoplankton and zooplankton communities in the coastal waters off Tongyeong in Korea. Ocean Polar Res 23:245-253

Legendre L, Michaud J (1999) Chlorophyll a to estimate the particulate organic carbon available as food to large zooplankton in the euphotic zone of oceans. J Plankton Res 21:2067-2083

Levins R (1968) Evolution in changing environments: some theoretical explorations. Princeton University Press, Princeton, NJ

> Lombard F, Sciandra A, Gorsky G (2005) Influence of body mass, food concentration, temperature and filtering activity on the oxygen uptake of the appendicularian Oikopleura dioica. Mar Ecol Prog Ser 301:149-158

Lombard F, Sciandra A, Gorsky G (2009) Appendicularians ecophysiology. II. Reproducing clearance, growth, respiration and particles production of the appendicularian Oikopleura dioica by modeling its ecophysiology. J Mar Sys 78:617-629

> López-Urrutia A, Acuña JL (1999) Gut throughput dynamics in the appendicularian Oikopleura dioica. Mar Ecol Prog
Ser 191:195-205 (Erratum in Mar Ecol Prog Ser 193:310, 2000)

López-Urrutia A, Irigoien X, Acuña JL, Harris R (2003) In situ feeding physiology and grazing impact of the appendicularian community in temperate waters. Mar Ecol Prog Ser 252:125-141

López-Urrutia A, Harris RP, Smith T (2004) Predation by calanoid copepods on the appendicularian Oikopleura dioica. Limnol Oceanogr 49:303-307

López-Urrutia A, Harris RP, Acuña JL, Båmstedt U and others (2005) A comparison of appendicularian seasonal cycles in four distinct European coastal environments. In: Gorsky G, Youngbluth MJ, Deibel D (eds) Response of marine ecosystems to global change: ecological impact of appendicularians. GB Scientific Publisher, Paris, p 255-276

> Maar M, Nielsen TG, Gooding S, Tonnesson K and others (2004) Trophodynamic function of copepods, appendicularians and protozooplankton in the late summer zooplankton community in the Skagerrak. Mar Biol 144: 917-934

Madhupratap M, Devassy VP, Sreekumaran Nair SR, Rao TSS (1980) Swarming of pelagic tunicates associated with phytoplankton bloom in the Bay of Bengal. Indian J Mar Sci 9:69-71

Merien D (2003) Variabilité biooptique à différentes échelles spatiales et temporelles dans l'Atlantique nord-est: interprétations biogéochimiques. $\mathrm{PhD}$ thesis, Université Pierre et Marie Curie, Paris

Moore C (1994) In-situ, biochemical, oceanic, optical meters. Sea Technol 35:10-16

Morel A, Berthon JF (1989) Surface pigments, algal biomass profiles, and potential production of the euphotic layer: relationships reinvestigated in view of remote-sensing applications. Limnol Oceanogr 34:1545-1562

Nomura H, Murano M (1992) Seasonal variation of meso- and macrozooplankton in Tokyo Bay, central Japan. Mer (Paris) 30:49-56

> Norrbin MF, Davis CS, Gallager SM (1996) Differences in fine-scale structure and composition of zooplankton between mixed and stratified regions of Georges Bank. Deep-Sea Res II 43:1905-1924

> Ohtsuka S, Kubo N, Okada M, Gushima K (1993) Attachment and feeding of pelagic copepods on larvacean houses. J Oceanogr 49:115-120

Osorio IAC (2003) Appendicularians (Tunicata) of Banco Chinchorro, Caribbean Sea. Bull Mar Sci 73:133-140

Passow U, Shipe RF, Murray A, Pak DK, Brzezinski MA, Alldredge AL (2001) The origin of transparent exopolymer particles (TEP) and their role in the sedimentation of particulate matter. Cont Shelf Res 21:327-346

Pomeroy LR, Hanson RB, McGillivary PA, Sherr BF, Kirchman D, Deibel D (1984) Microbiology and chemistry of fecal products of pelagic tunicates: rates and fates. Bull Mar Sci 35:426-439

Purcell JE, Sturdevant MV, Galt CP (2005) A review of appendicularians as prey of invertebrate and fish predators. In: Gorsky G, Youngbluth MJ, Deibel D (eds) Response of marine ecosystems to global change: ecological impact of appendicularians. GB Scientific Publisher, Paris, p 359-435

Remsen A, Hopkins TL, Samson S (2004) What you see is not what you catch: a comparison of concurrently collected net, optical plankton counter, and shadowed image particle profiling evaluation recorder data from the northeast Gulf of Mexico. Deep-Sea Res I 51:129-151

Robison BH, Reisenbichler KR, Sherlock RE (2005) Giant larvacean houses: rapid carbon transport to the deep sea floor. Science 308:1609-1611 
Samson S, Hopkins T, Remsen A, Langebrake L, Sutton T, Patten J (2001) A system for high resolution zooplankton imaging. IEEE J Oceanic Eng 26:671-676

Sato R, Tanaka Y, Ishimaru T (2001) House production by Oikopleura dioica (Tunicata, Appendicularia) under laboratory conditions. J Plankton Res 23:415-423

Sato R, Tanaka Y, Ishimaru T (2003) Species-specific house productivity of appendicularians. Mar Ecol Prog Ser 259: 163-172

Sato R, Tanaka Y, Ishimaru T (2005) Clearance and ingestion rates of three appendicularian species, Oikopleura longicauda, O. rufescens and O. fusiformis. In: Gorsky G, Youngbluth MJ, Deibel D (eds) Response of marine ecosystems to global change: ecological impact of appendicularians. GB Scientific Publisher, Paris, p 189-206

Scheinberg RD, Landry MR, Calbet A (2005) Grazing of two common appendicularians on the natural prey assemblage of a tropical coastal ecosystem. Mar Ecol Prog Ser 294:201-212

Shiganova T (2005) Changes in appendicularian Oikopleura dioica abundance caused by invasion of alien ctenophores in the Black Sea. J Mar Biol Assoc UK 85:477-494

Silva TA, Neumann-Leitão S, Schwamborn R, Gusmão LMO, Nascimento-Vieira DA (2003) Diel and seasonal changes in the macrozooplankton community of a tropical estuary in Northeastern Brazil. Rev Bras Zool 20:439-446

Skaramuca B (1977) Distribution of Oikopleura longicauda and Oikopleura fusiformis (Appendicularia) in the Adriatic Sea. Rapp PV Réun Comm Int Expl Sci Mer Méditerr Monaco 24:147-148

Sommer F, Hansen T, Feuchtmayr H, Santer B, Tokle N, Sommer U (2003) Do calanoid copepods suppress appendicularians in the coastal ocean? J Plankton Res 25: 869-871

Sreekumaran Nair SR, Nair VR, Achuthankutty CT, Madhupratap M (1981) Zooplankton composition and diversity in western Bay of Bengal. J Plankton Res 3:493-508

Stemmann L, Youngbluth M, Robert K, Hosia A and others (2008) Global zoogeography of fragile macrozooplankton in the upper 100-1000 m inferred from the underwater video profiler. ICES J Mar Sci 65:433-442

Stibor H, Vadstein O, Lippert B, Roederer W, Olsen Y (2004) Calanoid copepods and nutrient enrichment determine population dynamics of the appendicularian Oikopleura dioica: a mesocosm experiment. Mar Ecol Prog Ser 270: $209-215$
Taguchi S (1982) Seasonal study of fecal pellets and discarded houses of Appendicularia in a subtropical inlet, Kaneohe Bay, Hawaii. Estuar Coast Shelf Sci 14:545-555

Tomita M, Shiga N, Ikeda T (2003) Seasonal occurrence and vertical distribution of appendicularians in Toyama Bay, southern Japan Sea. J Plankton Res 25:579-589

> Uitz J, Claustre H, Morel A, Hooker SB (2006) Vertical distribution of phytoplankton communities in Open Ocean: an assessment based on surface chlorophyll. J Geophys ResOceans 111, C08005, doi:10.1029/2005JC003207

> Uye S, Ichino S (1995) Seasonal variations in abundance, size composition, biomass and production rate of Oikopleura dioica (Fol) (Tunicata: Appendicularia) in a temperate eutrophic inlet. J Exp Mar Biol Ecol 189:1-11

- Vaissiere R, Seguin G (1984) Initial observations of the zooplankton microdistribution on the fringing coral reef at Aqaba (Jordan). Mar Biol 83:1-11

> Valentin JL, Monteiro-Ribas WM, Mureb MA, Pessotti E (1987) Sur quelques zooplanctontes abondants dans l'upwelling de Cabo Frio (Brésil). J Plankton Res 9: 1195-1216

> Vargas CA, González HE (2004) Plankton community structure and carbon cycling in a coastal upwelling system. I. Bacteria, microprotozoans and phytoplankton in the diet of copepods and appendicularians. Aquat Microb Ecol 34:151-164

> Vargas CA, Tönnesson K, Sell A, Maar M and others (2002) Importance of copepods versus appendicularians in vertical carbon fluxes in a Swedish fjord. Mar Ecol Prog Ser 241:125-138

Warren JD, Stanton TK, Benfield MC, Wiebe PH, Chu D, Sutor M (2001) In-situ measurements of acoustic target strengths of gas-bearing siphonophores. ICES J Mar Sci $58: 740-749$

Wilson JB (1990) Mechanisms of species coexistence: twelve explanations for Hutchinson's 'paradox of the plankton': evidence from the New Zealand plant communities. NZ J Ecol 13:17-42

Yang G, Wang Y (1988) Preliminary study on Appendicularia of the northern part of the South China Sea. In: Xu G, Morton B (eds) Proc 1st Symp on Marine Biology of the South China Sea. China Ocean Press, Beijing, p 143-154

Zubkov MV, López-Urrutia A (2003) Effect of appendicularians and copepods on bacterioplankton composition and growth in the English Channel. Aquat Microb Ecol 32: $39-46$ 
Appendix 1. Model formulation (see Lombard et al. 2009). Variables: $x$ : Food concentration available in the water; $H, D h, F p, R$ : cumulative amount of matter produced respectively in the form of houses, detritus in houses, faecal pellets and respiration. Aw, $S b$ and $G$ are respectively appendicularian weight and fraction of this weight invested in structural biomass or gonads. Fluxes: $F$, $I$ and $A$ : quantity of food respectively filtered, ingested and assimilated. $i$ and ae are ingestion and assimilation efficiency. $f_{g}$ is the fraction of assimilated food invested in gonads and depends on the maturity indicator mi. Other symbols are defined in Table 1

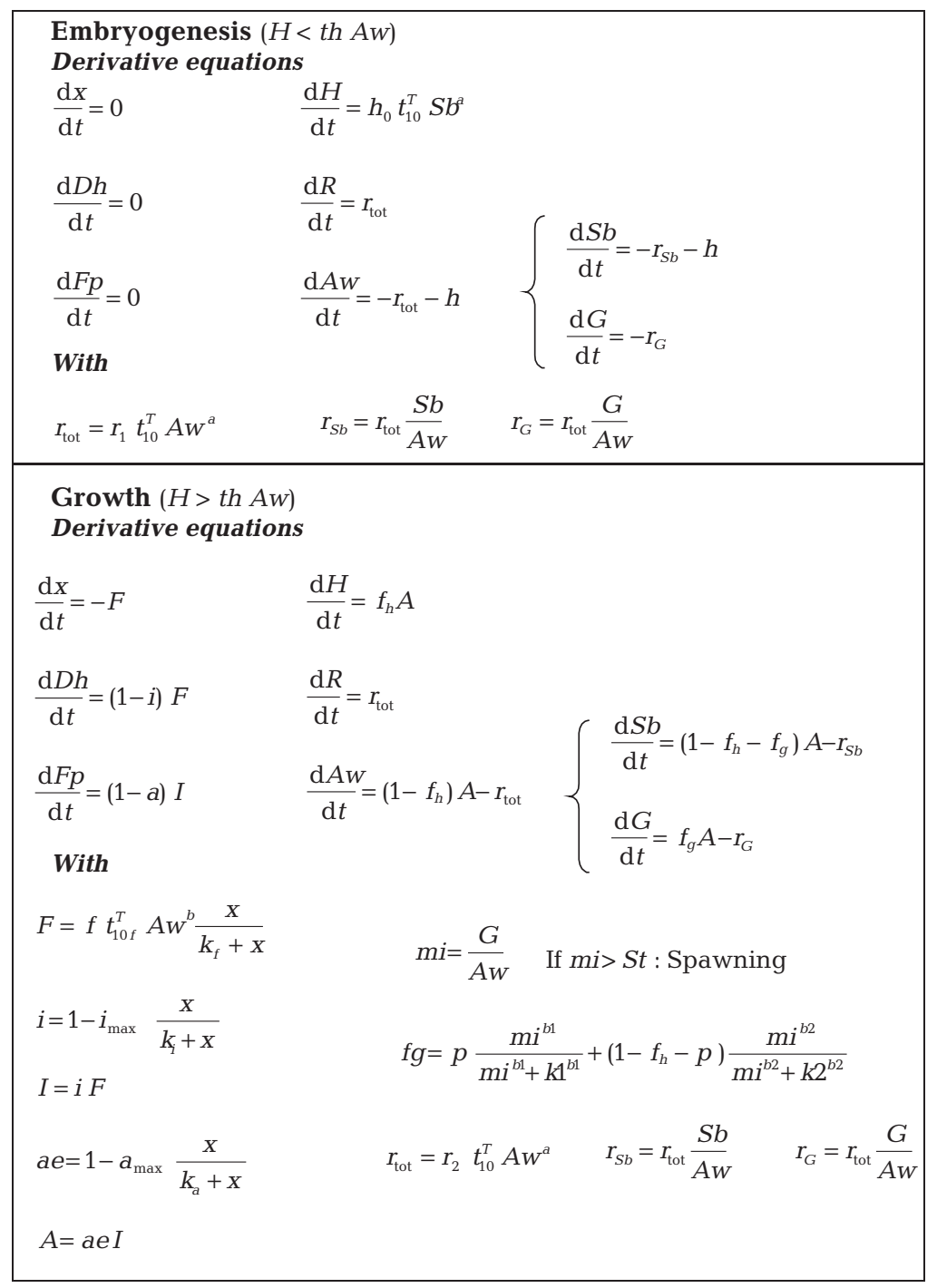

Editorial responsibility: Peter Verity, Savannah, Georgia, USA
Submitted: October 21, 2008; Accepted: August 17, 2009 Proofs received from author(s): November 24, 2009 